\title{
Lynch II syndrome: a case report
}

\author{
B Scotto*, E Spera, G Merola, D Di Simone \\ From XXIII Annual Meeting of the Italian Society of Geriatric Surgery \\ Lecce, Italy. 2-4 December 2010
}

\section{Background}

Lynch syndrome is an autosomal dominant cancer susceptibility syndrome that accounts for approximately $2-$ $4 \%$ of all colorectal cancers (CRCs) and is caused by germline mutations of mismatch repair (MMR) genes [1-4]. It is characterized by an early onset of predominantly CRC and endometrial cancer (EC) as well as cancers of the stomach, small bowel, ureter and renal pelvis.

\section{Materials and methods}

We report a case of a patient 60 years old affected by synchronous primary cancers of the sigma and stomach diagnosed by TC. The patient had previously been operated on for the right hemicolectomy for adenocarcinoma, and hysterectomy for cancer. During hospitalization the patient has undergone surgery on the left hemicolectomy and a total gastrectomy. The patient underwent chemotherapy. Currently the patient is receiving chemotherapy for local recurrence.

\section{Results}

As a result of genetic study, the patient was found to be the first to have this mutation.

\section{Conclusions}

Surgery remains the front-line therapy for HNPCC. There is an ongoing controversy over the benefit of 5fluorouracil-based adjuvant therapies for HNPCCrelated colorectal tumors, particularly those in stages I and II. After reporting a null finding from their randomized controlled trial of aspirin (ASA) to prevent against the colorectal neoplasia of Lynch Syndrome, Burn and colleagues have recently reported new data, representing a longer follow-up period than reported in the initial NEJM paper. These new data demonstrate a

\footnotetext{
* Correspondence: segreteriadisalvo@gmail.com Department of Surgical, Anesthesiologic and Emergency Sciences. University "Federico II", Naples, Italy
}

reduced incidence in Lynch Syndrome patients who were exposed to at least four years of high-dose aspirin, with a satisfactory risk profile. These results have been widely covered in the media; future studies will look at modifying (lowering) the dose (to reduce risk associated with the high dosage of ASA).

Published: 24 August 2011

\section{References}

1. Fishel R: The human mutator gene homolog $M \mathrm{MSH}_{2}$ and its association with hereditary nonpolyposis colon cancer. Cell 1993, 75:1027-38.

2. Bronner CE: Mutation in the DNA mismatch repair gene homologue hMLH1 is associated with hereditary non-polyposis colon cancer. Nature 1994, 368:258-61.

3. Miyaki M: Germline mutation of MSH6 as the cause of hereditary nonpolyposis colorectal cancer. Nat Genet 1997, 17:271-2.

4. Nicolaides NC: Papadopoulos Mutations of two PMS homologues in hereditary nonpolyposis colon cancer. Nature 1994, 371:75-80.

5. Renda A, Relazione Biennale SIC: Multiple Primary Malignant. SpringerVerlag Italia; 2009.

doi:10.1186/1471-2318-11-S1-A58

Cite this article as: Scotto et al:: Lynch II syndrome: a case report. BMC Geriatrics 2011 11(Suppl 1):A58

\section{Submit your next manuscript to BioMed Central and take full advantage of: \\ - Convenient online submission \\ - Thorough peer review \\ - No space constraints or color figure charges \\ - Immediate publication on acceptance \\ - Inclusion in PubMed, CAS, Scopus and Google Scholar \\ - Research which is freely available for redistribution \\ Submit your manuscript at www.biomedcentral.com/submit \\ C Biomed Central}

\section{Biomed Central}

